The Bulletin of the Dnipropetrovsk university. Series: Management of innovations Issue 7, Volume 24 (2016)

DOI: $10.15421 / 191617$

Received: 15 Oct 2016

Accepted: 11 Dec 2016

Published: 25 Dec 2016

\title{
Influence of the expenditures for the innovation activity on the foreign trade of Ukraine
}

\section{R. D. Bodnar ${ }^{\ddagger}$}

\begin{abstract}
An important task under current economic activity conditions is to find the interrelations between different economic indices and to study the character of these relationships.

The purpose of this article is to establish a dependence of the export of goods and services from Ukraine on the expenditures for innovation activity.

The study is based on data from the official internet resource of the State Statistics Services of Ukraine for 2000-2015. The method of correlation and regression analysis, graphical method, statistical and econometrical methods were used for the research.

It was revealed that the export of goods and services is correlated with expenditures for the research and development and for the acquisition of other external knowledge. Multiple linear regressions were found for these relationships. The dynamics of the coefficients of values of the export of goods and services from Ukraine for UAH 1 spent on innovation activity in Ukraine over 2000-2015 was also investigated. Finally, the predictions for these coefficients were found for 2016-2017.

The novelty of present research is in the quantitative research estimation of the dependence of the export of goods and services of innovation activity of Ukraine as well as the application of the iNZight software program for this analysis. The results received can be used in practice by managing export activity through factors that affect it. The dependence of other indices of the innovation activity of Ukraine on its foreign trade can be expanded in further studies.
\end{abstract}

Keywords: export of goods; export of services; innovation activity; correlation; linear regression; point forecast; error of prediction; autocorrelation.

JEL Classification M10; Noo; L2.
${ }^{\ddagger}$ Rostyslav Dmytrovych Bodnar, Doctor of science of physics and mathematics, docent, Postdoc, Institute for Statistics,

University of Bremen, Bremen, Germany, e-mail: ros.bodnar@gmail.com 


\section{Вплив витрат \\ на інноваційну діяльність України на її зовнішню торгівлю}

\author{
P.А.Боднар \\ Бременський університет, \\ Бремен, Німеччина
}

У сучасних умовах господарювання важливе завдання виявлення взаємозв'язків між економічними показниками і дослідження їх характеру.

Метою роботи - вивчення залежності експорту товарів і послуг з України від витрат на інноваційну діяльність.

Дослідження ґрунтувалося на даних, отриманих з офіційного сайту Державної служби статистики України за 2000-2015 рр. Аля проведення дослідження застосовано кореляційнорегресійний аналіз, графічний, статистичні і економетричні методи.

На основі здійсненого аналізу встановлено, що експорт товарів і послуг корелює з витратами на дослідження і розробки та також залежить від придбання інших зовнішніх знань. Побудовано лінійні множинні регресії, які описують цю залежність. Також досліджено динаміку у 2000-2015 pp. i побудовано прогноз на 2016-2017 рр. величин експорту товарів і послуг з України на 1 гривню, витрачену на інноваційну діяльність України.

Новизна дослідження полягає в кількісному дослідженні залежності експорту товарів і послуг від інноваційної діяльності України, а також використанні програми iNZight для цього аналізу.

Отримані результати можуть бути використані для регулювання обсягу експорту через фактори, які на нього впливають.

у подальшому можна досліджувати залежність показників зовнішньої торгівлі України від інших показників її інноваційної діяльності.

Ключові слова: експорт товарів; експорт послуг; інноваційна діяльність; кореляція; лінійна регресія; точковий прогноз; похибка прогнозу; автокореляція.

\section{Влияние расходов \\ на инновационную деятельность Украины на ее внешнюю торговлю}

\author{
Р. А. Боднар \\ Бременский университет, \\ Бремен, Германия
}

В современных условиях хозяйствования важной задачей является выявления взаимосвязей между экономическими показателями и исследование их характера.

Цель работы - изучение зависимости экспорта товаров и услуг с Украины от затрат на инновационную деятельность.

Исследование базировалось на данных, полученных с официального сайта Государственной службы статистики Украины за 2000-2015 гг. Аля проведения исследования применены метод корреляционно-регрессионного анализа, графический метод, статистические и эконометрические методы.

На основе проведенного анализа установлено, что экспорт товаров и услуг коррелирует с затратами на исследования и разработки, а также зависит от приобретения других внешних знаний. Построены линейные множественные регрессии, описавшие эту зависимость. Исследована динамика в 20002015 гг. и на 2016-2017 гг. построен прогноз величин экспорта товаров и услуг из Украины в расчете на 1 гривну, потраченную на инновационную деятельность Украины.

Новизна исследования заключается в количественном исследовании зависимости экспорта товаров и услуг от инновационной деятельности Украины, а также использовании программы iNZight для этого анализа. Полученные результаты можна применять для регулирования объема экспорта с помощью факторов, на него влияющих.

В дальнейшем можно исследовать зависимость показателей внешней торговли Украины от других показателей ее инновационной деятельности.

Ключевые слова: экспорт товаров; экспорт услуг; инновационная деятельность; корреляция; линейная регрессия; точечный прогноз; ошибка прогноза; автокорреляция. 


\section{Introduction}

he dependence of export of goods and services from Ukraine $\langle$ Ton its expenditures for the innovation activity is explored in this article. The total sum of expenses on the innovation activity as well as its components of financing sources and innovation activities was chosen for this analysis. Official data of the chosen indices can be found at the official internet website of the State Statistics Services of Ukraine [6]. The research is carried out for the annual data of these indices over 2000-2015.

Innovation activity and foreign trade play an important role in the economics of a country. Foreign trade in goods and services has a significant impact on the gross domestic product (Ivanenko, 2011) [1]. There are some academic papers, which have already tackled foreign trade and innovation activity in Ukraine. Mazaraki and Melnyk (2012) analyzed the determinants for Ukraine of the development of its foreign trade by innovative products in their article [2]. Melnyk and Zubko (2011) investigated the innovations in the goods' structure of the Ukrainian foreign trade [3]. Kyzym et al. (2014) studied foreign trade in the production of high-tech industries of Ukraine after it joined the WTO [4]. Meh (2011) identified separate groups of industrial products with different degrees of scientific intensity in the goods' structure of foreign trade of Ukraine and estimated their influence on the innovation development of Ukraine in [5].

\section{Research Question}

he aim of the paper is to establish how the indices of the T innovation activity of Ukraine, the statistical data about 1 which can be found on the website of the State Statistics Services of Ukraine, affect its foreign trade. The first group of such indices is the sum of expenses according to innovation activities. This group consists of the following expenditures: for research and development, for the acquisition of other external knowledge and for the acquisition of machinery, equipment, and software.

\section{Method and Data}

he econometrical methods, given, in particular, in the book T by Yeleyko, Bodnar and Demchyshyn (2011) [7], are used for the further studies. The Excel and iNZight programs are used as software for analysis. INZight is a statistical programming language $\mathrm{R}$ package. It allows for easy and quick exploration of statistical data, as well as building different statistical graphs, and analyzing time series.

The data on foreign trade are given in USD at the official website of the State Statistics Services of Ukraine. And the data on the innovation activities are given in UAH. Thus, these data should be reduced to the same units first of all. For this purpose, data on the foreign trade is multiplied by the corresponding values of the average official exchange rate of UAH against the USD taken from the official website of the National Bank of Ukraine [8]. Since the initial data is annual, the official exchange rate is annual too. Next, under consideration of the inflation rate during corresponding periods, all data are adjusted to the prices as of 2015.

Correlation coefficients are computed in order to identify the relationship between the total sum of expenses on the innovation activity of Ukraine and export of goods and services. The correlation coefficient between export of goods from Ukraine and the sum of expenses on the innovation activity is equal to 0.43 (significance level $\alpha=0,096$ ). The correlation coefficient between export of services from Ukraine and the given sum of expenses is equal to $0.14(\alpha=0,605)$. And the correlation coefficient between the export of goods and services in general and the sum of expenses on the innovation activity is equal to $0.38(\alpha=0,147)$.
Thus, we may conclude that there is no linear relationship between the sum of expenses and established indices of the export. Therefore, there are two possibilities: either there exists a nonlinear relationship between considered indices or there is no relationship between them at all. We will use the graphical methods to check which of them is correct.

Graphs of dependence of export of goods, services and in general on the expenses on the innovation activity are given in Fig. 1 and 2.

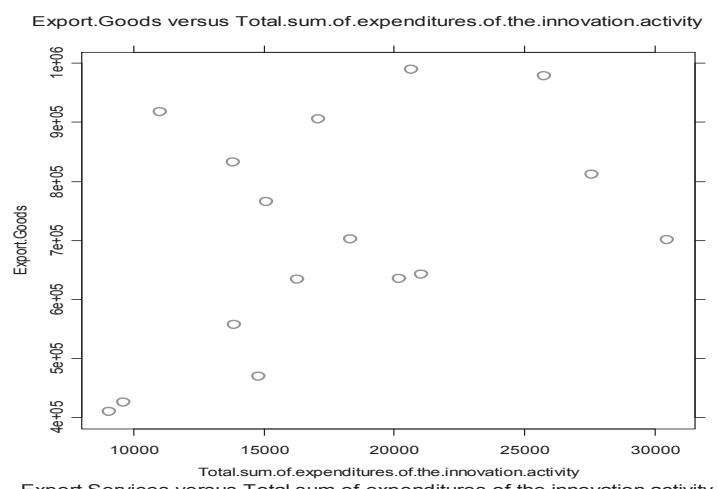

Export.Services versus Total.sum.of expenditures of the innovation. activity

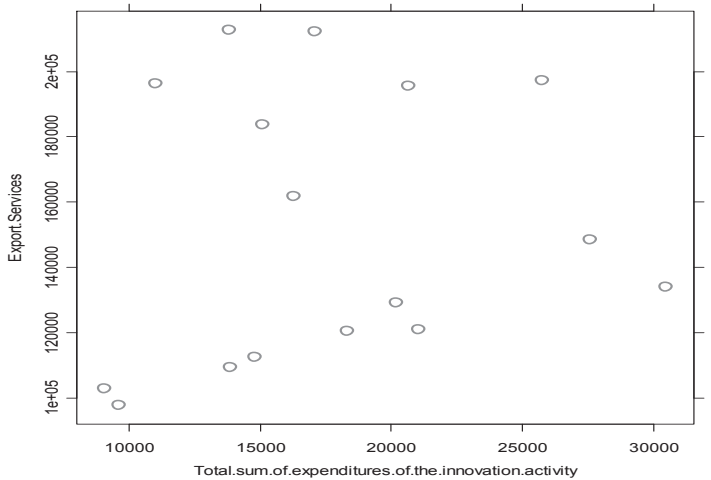

Fig. 1. Relationship between export of goods and services from Ukraine and the total sum of expenditure on the innovation activity of Ukraine over 2000-2015, UAH million Source: compiled by the author, based on [6].

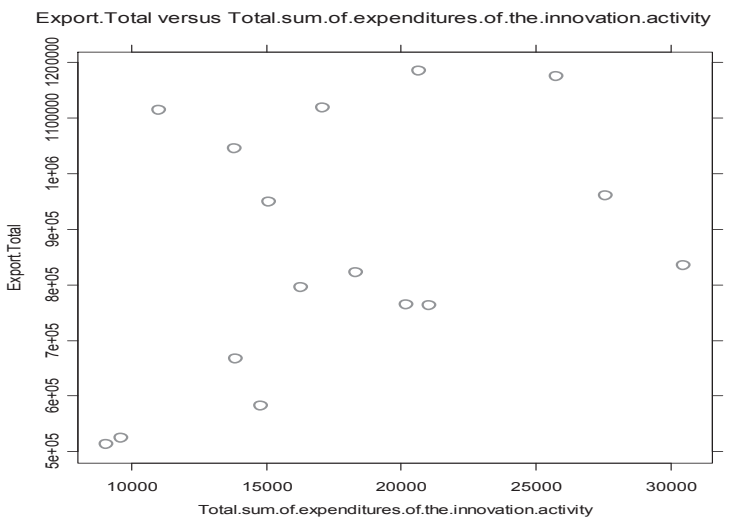

Fig. 2. Relationship between export of goods and services in total from Ukraine and the total sum of expenditure on the innovation activity of Ukraine over 2000-2015, UAH million

Source: compiled by the author, based on [6].

There are no clearly visible tendencies of these processes in their graphs. Thus, a conclusion about the absence of relationship of the sum of expenses on the innovation activity of Ukraine and investigated indices of its export, based on these graphs, is drawn. 


\section{Results}

he first group of indices of the innovation activity of Ukraine $\langle\mathrm{T}\rangle$ is the sum of expenses according to innovation activities. This group consists of the following expenditures: for research and development, for the acquisition of other external knowledge and for the acquisition of machinery, equipment, and software. We denote by $r$ the pair correlation coefficients and by $\alpha$ the corresponding significance level. Then the next table 1 is obtained.

Table 1

Values of pair correlation coefficients between indices of export of goods and services from Ukraine and areas of financing of innovation activities of Ukraine over 2000-2015

\begin{tabular}{|c|c|c|c|c|c|c|c|c|c|c|c|c|}
\hline & \multicolumn{2}{|c|}{ Export of goods } & \multicolumn{2}{|c|}{$\begin{array}{l}\text { Export of } \\
\text { services }\end{array}$} & \multicolumn{2}{|c|}{ Export in total } & \multicolumn{2}{|c|}{$\begin{array}{l}\text { Expenditures } \\
\text { for research } \\
\text { and } \\
\text { development }\end{array}$} & \multicolumn{2}{|c|}{$\begin{array}{l}\text { Expenditures } \\
\text { for the } \\
\text { acquisition of } \\
\text { other external } \\
\text { knowledge }\end{array}$} & \multicolumn{2}{|c|}{$\begin{array}{c}\text { Expenditures for the } \\
\text { acquisition } \\
\text { of machinery, } \\
\text { equipment, } \\
\text { and software }\end{array}$} \\
\hline & $r$ & $\alpha$ & $r$ & $\alpha$ & $r$ & $\alpha$ & $r$ & $\alpha$ & $r$ & $\alpha$ & $r$ & $\alpha$ \\
\hline Export of goods & 1.000 & 0.000 & 0.889 & 0.000 & 0.996 & 0.000 & 0.501 & 0.048 & -0.584 & 0.018 & 0.199 & 0.460 \\
\hline Export of services & 0.889 & 0.000 & 1.000 & 0.000 & 0.924 & 0.000 & 0.299 & 0.261 & -0.728 & 0.001 & 0.073 & 0.788 \\
\hline Export in total & 0.996 & 0.000 & 0.924 & 0.000 & 1.000 & 0.000 & 0.472 & 0.065 & -0.620 & 0.010 & 0.179 & 0.507 \\
\hline $\begin{array}{l}\text { Expenditures } \\
\text { for research } \\
\text { and development }\end{array}$ & 0.501 & 0.048 & 0.299 & 0.261 & 0.472 & 0.065 & 1.000 & 0.000 & 0.131 & 0.629 & 0.555 & 0.026 \\
\hline $\begin{array}{l}\text { Expenditures for the } \\
\text { acquisition of other } \\
\text { external knowledge }\end{array}$ & -0.584 & 0.018 & -0.728 & 0.001 & -0.620 & 0.010 & 0.131 & 0.629 & 1.000 & 0.000 & 0.504 & 0.047 \\
\hline $\begin{array}{l}\text { Expenditures } \\
\text { for the acquisition } \\
\text { of machinery, } \\
\text { equipment } \\
\text { and software }\end{array}$ & 0.199 & 0.460 & 0.073 & 0.788 & 0.179 & 0.507 & 0.555 & 0.026 & 0.504 & 0.047 & 1.000 & 0.000 \\
\hline
\end{tabular}

*Source: compiled by the author, based on [6].

Table 1 shows that expenditures for the acquisition of machinery, equipment and software are weakly correlated with the established export's indices. Therefore, multiple linear regressions of dependence of export of goods (model 1), services (model 2) and in general (model 3) on the expenditures for research and development (variable $\mathrm{A}$ ) and the expenditures for the acquisition of other external knowledge (variable B) are calculated. Received results are given in the following table 2 .

Table 2

Multiple linear regressions of dependence of export of goods, services and in general on the expenditures for research and development and the expenditures for the acquisition of other external knowledge over 2000-2015*

\begin{tabular}{|c|c|c|c|c|c|c|c|c|c|}
\hline \multirow{2}{*}{ Model } & \multicolumn{2}{|c|}{ Unstandardized coefficients } & \multirow{2}{*}{$\begin{array}{c}\begin{array}{c}\text { Standardized } \\
\text { coefficients }\end{array} \\
\text { Beta }\end{array}$} & \multirow{2}{*}{$\mathrm{t}$} & \multirow{2}{*}{$\begin{array}{c}\text { Significanc } \\
\text { e level }\end{array}$} & \multirow{2}{*}{ R-squared } & \multirow{2}{*}{$\begin{array}{l}\text { Adjusted } \\
\text { R-squared }\end{array}$} & \multirow{2}{*}{ F-statistic } & \multirow{2}{*}{ p-value } \\
\hline & B & $\begin{array}{c}\text { Standard } \\
\text { error }\end{array}$ & & & & & & & \\
\hline $\begin{array}{c}1 \text { (constant) } \\
\text { variable } A \\
\text { variable } B\end{array}$ & $\begin{array}{r}553710.508 \\
138.056 \\
-336.447\end{array}$ & $\begin{array}{r}96178.180 \\
37.196 \\
80.649\end{array}$ & $\begin{array}{r}0.587 \\
-0.660\end{array}$ & $\begin{array}{r}5.757 \\
3.712 \\
-4.172 \\
\end{array}$ & $\begin{array}{l}0.000 \\
0.003 \\
0.001\end{array}$ & 0.680 & 0.631 & 13.804 & 0.001 \\
\hline $\begin{array}{c}2 \text { (constant) } \\
\text { variable } \mathrm{A} \\
\text { variable } \mathrm{B}\end{array}$ & $\begin{array}{r}147099.976 \\
20.819 \\
-87.927\end{array}$ & $\begin{array}{r}21044.713 \\
8.139 \\
17.647 \\
\end{array}$ & $\begin{array}{r}0.400 \\
-0.780 \\
\end{array}$ & $\begin{array}{r}6.990 \\
2.558 \\
-4.983\end{array}$ & $\begin{array}{l}0.000 \\
0.024 \\
0.000 \\
\end{array}$ & 0.687 & 0.639 & 14.264 & 0.001 \\
\hline $\begin{array}{c}3 \text { (constant) } \\
\text { variable } A \\
\text { variable } B\end{array}$ & $\begin{array}{r}700810.484 \\
158.875 \\
-424.374\end{array}$ & $\begin{array}{r}112555.075 \\
43.530 \\
94.381\end{array}$ & $\begin{array}{r}0.563 \\
-0.694\end{array}$ & $\begin{array}{r}6.226 \\
3.650 \\
-4.496\end{array}$ & $\begin{array}{l}0.000 \\
0.003 \\
0.001\end{array}$ & 0.696 & 0.649 & 14.881 & 0.000 \\
\hline
\end{tabular}

*Source: compiled by the author, based on [6].

Thus, the export of goods from Ukraine increases by UAH 138.056 million, on average, if the expenditures for research and development increase by UAH 1 million and for a fixed value of expenditures for the acquisition of other external knowledge. And the export of goods from Ukraine decreases by UAH 336.447 million, on average, if the expenditures for the acquisition of other external knowledge increase by UAH 1 million and for a fixed value of expenditures for research and development. The export of services from Ukraine increases by UAH 20.819 million, on average, if the expenditures for research and development increase by UAH 1 million and for a fixed value of expenditures for the acquisition of other external knowledge. And it decreases by UAH 87.927 million, on average, if the expenditures for the acquisition of other external knowledge increase by UAH 1 million and for a fixed value of expenditures for research and development.

The export in total from Ukraine increases by UAH 158.875 million, on average, if the expenditures for research and development increase by UAH 1 million and for a fixed value of expenditures for the acquisition of other external knowledge and decreases, on average, by UAH 424.374 million if the expenditures for the acquisition of other external knowledge increase by UAH 1 million and for a fixed value of expenditures for research and development.

All constructed models describe more than $68 \%$ of variations of the established indices of the export. Finally, the absence of multicollinearity in these models follows from the low value of pair correlation coefficient between their factors, which is equal to 0.131 .

The second group of indices of the innovation activity of Ukraine, the statistical data about which can be found on the website of the State Statistics Services of Ukraine, is the sum of expenses according to the financing sources. This group consists of the following indices: own funds of enterprises, funding from the state budget and funding by foreign investors (table 3 ). 
Values of pair correlation coefficients between indices of export of goods and services from Ukraine and financing sources of the innovation activity of Ukraine over $2000-2015^{*}$

\begin{tabular}{|c|c|c|c|c|c|c|}
\hline \multirow{3}{*}{ Export } & \multicolumn{6}{|c|}{ Cost of financing the innovation activities of Ukraine } \\
\hline & \multicolumn{2}{|c|}{ own funds } & \multicolumn{2}{|c|}{ state budget } & \multicolumn{2}{|c|}{ foreign investors } \\
\hline & $r$ & $\alpha$ & $r$ & $\alpha$ & $r$ & $\alpha$ \\
\hline goods & 0.273 & 0.306 & 0.215 & 0.424 & 0.073 & 0.788 \\
\hline services & 0.010 & 0.971 & -0.075 & 0.783 & 0.273 & 0.306 \\
\hline in total & 0.385 & 0.141 & 0.229 & 0.394 & 0.165 & 0.541 \\
\hline
\end{tabular}

"Source: compiled by the author, based on [6].

Let us remind that $r$ denotes the pair correlation coefficients and $\alpha$ denotes the corresponding significance level in Table 3 . It follows from Table 3 that the indices of export of goods and services are uncorrelated with financing sources of the innovation activity of Ukraine. Similar graphical analysis in Figures 1 and 2 provides for the conclusion about the absence of relationships between indices of export of goods and services from Ukraine and own funds of enterprises, funding from the state budget and funding by foreign investors. Let us consider in more detail one of such graphs, which demonstrate dependence of export of services on the own funds of enterprises.

It follows from Fig. 3 that there is no any relationship between export of services from Ukraine and own funds of enterprises.

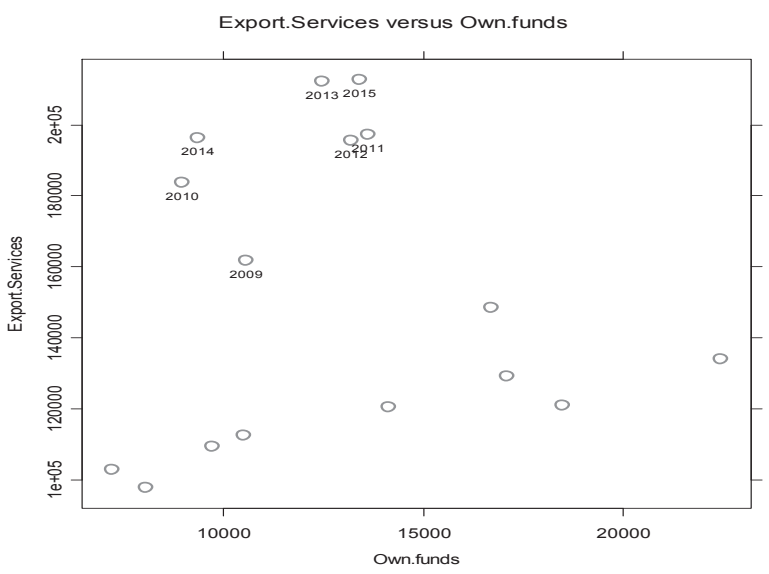

Fig. 3. Dependence of export of services on the own funds of enterprises, spent on innovation activities

in Ukraine over 2000-2015, UAH million*

*Source: compiled by the author, based on [6].

At the same time, one can see that there was a linear relationship between these indices up to 2008. The results of this relationship are given in the following table. Enterprises have spent less money on the innovation activity after 2009, as well as export of services from Ukraine increased, and this broke down the relationship, mentioned before, given in Table 4 .

Finally, let us consider coefficients, which show the part of export of goods $\left(\boldsymbol{C}_{g}\right)$, services $\left(\boldsymbol{C}_{s}\right)$ and in total $\left(\boldsymbol{C}_{t}\right)$ relative to $\mathrm{UAH} 1$ spent on innovation activity of Ukraine. These coefficients can be computed as

$$
C_{g}=E_{g} / 1 \quad A, C_{s}=E_{s} / 1 \quad A, C_{t}=E_{t} / I \quad A \text {, }
$$

where $E_{g}, E_{s}$ and $E_{t}$ are the export of goods, services and in general, respectively, and IA denotes expenditures on innovation activity of Ukraine. Dynamics of these coefficients for 2000-2015 is given in Table 5.

It follows from table 5 that the dynamic of established coefficients can be better described by parabolic trends.

These trends describe from $71.5 \%$ to $77.8 \%$ of the indices' variation. Moreover, empirical values of the Darbin-Watson criterion are equal to $2.549,2.032$ and 2.485 for parabolic rends of $\boldsymbol{C}_{\mathrm{g}}, \boldsymbol{C}_{\mathrm{s}}$ and $\boldsymbol{C}_{\mathrm{t}}$, respectively. These values are rather close to 2 . Thus we can state that there are no autocorrelation of rests in parabolic trends. $p$ values for the F-statistic are smaller than 0,05. Therefore, forecasts of the considered coefficients, based on the parabolic trends for 2016-2017, can be made with probability $p=0,95$ (table 6).

Thus, it can be stated with probability $p=0,95$ that the coefficient of values of export of goods from Ukraine per UAH 1 to be spent on innovation activity of Ukraine is expected between 57.957 and 105.109 in 2016 and between 53.014 and 130.492 in 2017. The coefficient of values of export of services from Ukraine per UAH 1 to be spent on innovation activity of Ukraine is expected between 14.466 and 25.082 in 2016 and between 16.686 and 25.551 in 2017. And the coefficient of values of export from Ukraine in total per $\mathrm{UAH} 1$ to be spent on innovation activity of Ukraine is expected with probability $p=0,95$ between 73.084 and 129.531 in 2016 and between 82.828 and 145.915 in 2017.

Linear regression of export of services on the own funds of enterprises, spent on innovation activity in Ukraine over 2000-2008*

\begin{tabular}{|c|c|c|c|c|c|c|c|c|c|}
\hline \multirow{2}{*}{ Model } & \multicolumn{2}{|c|}{ Unstandardized coefficients } & \multirow{2}{*}{$\begin{array}{c}\text { Standardized } \\
\text { coefficients } \\
\text { Beta }\end{array}$} & \multirow{2}{*}{$\mathrm{t}$} & \multirow{2}{*}{$\begin{array}{c}\text { Significance } \\
\text { level }\end{array}$} & \multirow{2}{*}{ R-squared } & \multirow{2}{*}{$\begin{array}{l}\text { Adjusted R- } \\
\text { squared }\end{array}$} & \multirow{2}{*}{ F-statistic } & \multirow{2}{*}{$\mathrm{p}$-value } \\
\hline & $\mathrm{B}$ & Standard error & & & & & & & \\
\hline $\begin{array}{c}1 \text { (constant) } \\
\text { variable } \mathrm{A}\end{array}$ & $\begin{array}{c}85045.269 \\
2.495\end{array}$ & $\begin{array}{c}9831.168 \\
0.670\end{array}$ & 0.815 & $\begin{array}{l}8.651 \\
3.724\end{array}$ & $\begin{array}{l}0.000 \\
0.007\end{array}$ & 0.665 & 0.617 & 13.871 & 0.007 \\
\hline
\end{tabular}

* Source: compiled by the author, based on [6]. 
Dynamics of coefficient of values of export of goods, services and in total from Ukraine per UAH 1 spent on innovation activity of Ukraine over 2000-2015*

\begin{tabular}{|c|c|c|c|c|c|c|c|c|c|c|c|}
\hline \multirow{2}{*}{$\begin{array}{c}\text { Ind } \\
\text { ex }\end{array}$} & \multicolumn{2}{|c|}{ Trend's model } & \multicolumn{2}{|c|}{$\begin{array}{c}\text { Unstandardized } \\
\text { coefficients }\end{array}$} & \multirow{2}{*}{$\begin{array}{c}\text { Standardized } \\
\text { coefficients } \\
\text { Beta }\end{array}$} & \multirow{2}{*}{$\mathrm{t}$} & \multirow{2}{*}{$\begin{array}{c}\text { Significance } \\
\text { level }\end{array}$} & \multirow{2}{*}{$\begin{array}{c}\text { R- } \\
\text { squared }\end{array}$} & \multirow{2}{*}{$\begin{array}{c}\text { Adjusted R- } \\
\text { squared }\end{array}$} & \multirow{2}{*}{$\begin{array}{c}\text { F- } \\
\text { statistic }\end{array}$} & \multirow{2}{*}{$\begin{array}{c}\mathrm{p}- \\
\text { value }\end{array}$} \\
\hline & type & coefficients & B & $\begin{array}{c}\text { Standard } \\
\text { error }\end{array}$ & & & & & & & \\
\hline$C_{g}$ & Linear & $\begin{array}{c}\text { (constant) } \\
t\end{array}$ & $\begin{array}{c}28.331 \\
1.712\end{array}$ & $\begin{array}{l}6.549 \\
0.677 \\
\end{array}$ & 0.560 & $\begin{array}{l}4.326 \\
2.527 \\
\end{array}$ & $\begin{array}{l}0.001 \\
0.024 \\
\end{array}$ & 0.313 & 0.264 & 6.386 & 0.024 \\
\hline$C_{g}$ & Parabolic & $\begin{array}{c}\text { (constant) } \\
t \\
t^{2}\end{array}$ & $\begin{array}{c}52.437 \\
-6.324 \\
0.473\end{array}$ & $\begin{array}{l}7.141 \\
1.933 \\
0.111\end{array}$ & $\begin{array}{l}-2.068 \\
2.703\end{array}$ & $\begin{array}{l}7.343 \\
-3.271 \\
4.275 \\
\end{array}$ & $\begin{array}{l}0.000 \\
0.006 \\
0.001\end{array}$ & 0.715 & 0.671 & 16.273 & 0.000 \\
\hline \multirow[b]{2}{*}{$C_{s}$} & Linear & $\begin{array}{c}\text { (constant) } \\
t\end{array}$ & $\begin{array}{l}5 \cdot 911 \\
0.410\end{array}$ & $\begin{array}{l}1.720 \\
0.178\end{array}$ & 0.524 & $\begin{array}{l}3.438 \\
2.303\end{array}$ & $\begin{array}{l}0.004 \\
0.037\end{array}$ & 0.275 & 0.223 & $5 \cdot 306$ & 0.037 \\
\hline & Parabolic & $\begin{array}{c}\text { (constant) } \\
t \\
t^{2}\end{array}$ & $\begin{array}{c}12.810 \\
-1.890 \\
0.135\end{array}$ & $\begin{array}{l}1.608 \\
0.435 \\
0.025 \\
\end{array}$ & $\begin{array}{l}-2.419 \\
3.028 \\
\end{array}$ & $\begin{array}{r}7.968 \\
-4.343 \\
5.435 \\
\end{array}$ & $\begin{array}{l}0.000 \\
0.001 \\
0.000 \\
\end{array}$ & 0.778 & 0.744 & 22.830 & 0.000 \\
\hline \multirow[b]{2}{*}{$C_{t}$} & Linear & $\begin{array}{c}\text { (constant) } \\
t\end{array}$ & $\begin{array}{c}34.242 \\
2.121\end{array}$ & $\begin{array}{l}8.186 \\
0.847\end{array}$ & 0.556 & $\begin{array}{l}4.183 \\
2.506 \\
\end{array}$ & $\begin{array}{l}0.001 \\
0.025 \\
\end{array}$ & 0.310 & 0.260 & 6.278 & 0.025 \\
\hline & Parabolic & $\begin{array}{c}\text { (constant) } \\
t \\
t^{2}\end{array}$ & $\begin{array}{c}65.247 \\
-8.214 \\
0.608\end{array}$ & $\begin{array}{l}8.548 \\
2.314 \\
0.132\end{array}$ & $\begin{array}{l}-2.155 \\
2.789\end{array}$ & $\begin{array}{c}7.633 \\
-3.549 \\
4.593\end{array}$ & $\begin{array}{l}0.000 \\
0.004 \\
0.001\end{array}$ & 0.737 & 0.696 & 18.195 & 0.000 \\
\hline
\end{tabular}

*Source: compiled by the author, based on [6].

Forecasts of coefficient of values of export of goods, services and in total from Ukraine per UAH 1 to be spent on innovation activity of Ukraine for 2016-2017*

\begin{tabular}{c|c|c|c}
\hline Coefficient & Year & Point forecast & Margin error of prediction \\
\hline \multirow{2}{*}{$C_{g}$} & 2016 & 81.533 & 23.576 \\
\cline { 2 - 4 } & 2017 & 91.753 & 38.734 \\
\hline \multirow{2}{*}{$C_{s}$} & 2016 & 19.774 & 5.308 \\
\cline { 2 - 4 } & 2017 & 22.619 & 5.932 \\
\hline \multirow{2}{*}{$C_{t}$} & 2016 & 101.307 & 28.223 \\
\cline { 2 - 4 } & 2017 & 114.372 & 31.544 \\
\hline
\end{tabular}

*Source: compiled by the author, based on [6].

\section{Conclusions}

here are no direct relationships between the indices of $\langle$ Texport from Ukraine and the expenditures for innovation activity of Ukraine in total, as well as relative to the financing sources of these expenditures. The export of goods and services from Ukraine separately, as well as in total, are well described by multiple linear regressions of their dependence on the sums of expenditures for research and development and for the acquisition of other external knowledge.

Coefficients of values of export of goods, services and in total from Ukraine per UAH 1 spent on innovation activity of Ukraine were established. Dynamics of these coefficients over 2000-2015 can be described by using parabolic trends, which also demonstrate further growth of the considered indices. Constructed trends correspond to the initial data with $p$-value less than 0.05 according to the Fisher criterion. Therefore, one can use them for the considered coefficients forecasting with probability 0.95 . The point forecasts for the established coefficients were found for 2016-2017, as well as their confidence intervals for significance level 0.05 .

The novelty of present research is in the quantitative research estimation of dependence of export of goods and services on the innovation activity of Ukraine, as well as the application of the iNZight program for this analysis. The results received can be used in practice by managing export through factors that affect it. Dependence of other indices of the innovation activity of Ukraine on its foreign trade can be expanded in further studies.

\section{Bibliographic references}

1. Іваненко, І. А. Аналіз впливу зовнішньої торгівлі з країнами СНД на ВВП України [Текст] / І. А. Іваненко // Вісник Маріупольського державного університету. Серія Економіка. - 2011. - Вип. 2. - С. 166-174.

2. Мазаракі, А. Детермінанти розвитку зовнішньої торгівлі України інноваційною продукцією [Текст] / А. Мазаракі, Т. Мельник // Вісн. Київ. нац. торговельно-екон. ун-ту. 2012. - № 2. - C. 5-20.

3. Мельник, Т.М. Інноваційний регрес у товарній структурі зовнішньої торгівлі України [Текст] / Т. М. Мельник, О. В. Зубко // Маркетинг і менеджмент інновацій. - 2011. - № 4(2). - C. 192-199.

4. Можливості і загрози від членства України в СОТ у зовнішній торгівлі продукцією високотехнологічних галузей в умовах співпраці з країнами $\in C$ і митного союзу ЄврАзЕС [Текст] / М. О. Кизим, І. Ю. Матюшенко, В. Є. Хаустова, О. В. Козирєва, А. М. Костенко, Ю. М. Моісеєнко, І. Ю. Бунтов // Проблеми економіки. 2014.- №1. - C. 6-25.

5. Мех, О. А. Товарна структура зовнішньої торгівлі України як індикатор науково-технологічного та інноваційного розвитку економіки [Текст] / О.А. Мех // Наука та наукознавство. - 2011. - № 3. - С. 24-38. 
6. Офіційний сайт Державної служби статистики України [Електронний ресурс]. - Режим доступу: http://www.ukrstat.gov.ua. - Загл. з екрана.

7. Єлейко, В.І. Економетричний аналіз діяльності підприємств [Текст] / В.І. Єлейко, Р.А. Боднар, М. Я. Демчишин. Тернопіль: Навч. книга-Богдан, 2011. - 362 с.

8. Офіційний сайт Національного банку України [Електронний ресурс]. - Режим доступу: https://bank.gov.ua/files/ Exchange_r.xls. - Загл. з екрана.

\section{References}

lelejko, V. I., Bodnar, R. D., \& Demchyshyn, M. la. (2011) Ekonometrychnyj analiz diial'nosti pidpryiemstv. Navchal'na knyha-Bohdan, Ternopil' (in Ukrainian).

Ivanenko, I. A. (2011) Analiz vplyvu zovnishnioii torgivli z kraiinamy SND na VVP Ukraiiny [Foreign Trade with CIS Countries Influence Analysis on GDP of Ukraine]. Visnyk Mariupolskoho derzhavnoho universytetu. Seriia Ekonomika, 2, 166-174 (in Ukrainian).

Kyzym, M. O., Matiushenko, I. Y., Khaustova, V. Y., Kostenko, D. M., Moiseienko, Y. M., \& Buntov, I. Y. (2014). Mozhlyvosti i zagrozy vid chlenstva Ukraiiny v SOT u zovnishnij torgivli produktziieiu vysokotehnolohichnyh haluzej $v$ umovah spivpratzi z kraiinamy les i Mytnogo soiuzu levrAzES
[Opportunities and threats of WTO membership of Ukraine in foreign trade of high-technology products under conditions of co-operation with EU countries and Customs Union of Belarus, Kazakhstan, and Russia]. Problemy ekonomiky, 1, 24-38 (in Ukrainian).

Mazaraki, A., \& Melnik, T. (2012) Determinanty rozvytku zovnishnioii torgivli Ukraiiny innovatzijnoiu productziieiu [Determinants of Ukraine's foreign trade development of innovative products]. Visnyk Kyiivs'koho natzional'noho torgovel'no-ekonomichnoho universytetu, 2, 5-20 (in Ukrainian).

Meh, O. A. (2011) Tovarna struktura zovnishnioii torhivli Ukraiiny iak indykator naukovo-tehnichnoho ta innovatzijnoho rozvytku ekonomiky. Nauka ta naukoznavstvo, 3, 24-38 (in Ukrainian).

Melnyk, T. M., \& Zubko, O. V. (2011) Innovatzijnyj regres u tovarnij strukturi zovnishnioii torgivli Ukraiiny [Innovative regression in the foreign trade commodity structure of Ukraine]. Marketynh i menedzhment, 4(2), 192-199 (in Ukrainian).

Ofitzijnyj sajt Derzhavnoii sluzhby statystyky Ukraiiny. Retrieved from http://www.ukrstat.gov.ua.

Ofitzijnyj sajt Natzional'noho banku Ukraiiny Ukraiiny Retrieved from https://bank.gov.ua/files/Exchange_r.xls. 